\section{Voting Rights, Private Benefits, and Takeovers}

\author{
Frank A. Schmid
}

T his article presents a textbook exposition of the effects that institutional design of the firm has on allocation of control over assets. The efficient allocation of control over the assets bundled up in the firm is necessary for the optimal allocation of its resources. Dynamic efficiency in resource allocation presupposes that control over firms will change hands when a given allocation turns suboptimal. The institutional framework within which control changes hands is called the market for corporate control. This market is closely linked to the stock market as control rights over the assets of the firm are linked to voting stock. We analyze how the allocation of shareholder voting rights and other organizational designs of the firm affect the firm's stock market valuation and the allocation of control over its assets.

Transactions in the market for corporate control have increased greatly over the last decade both in number and value. Figure 1 shows that in the United States the number of acquisitions of publicly traded companies quadrupled between a trough in 1991 and a recent peak in 1999. Measured in dollar terms (without inflation adjustment), the rise in acquisitions of publicly traded companies was 30-fold during that period. Among the 50 industries distinguished by Mergerstat (2000, pp. 61 -69), "Banking $\&$ Finance" was among the seven most active industries in any year in the 1996-2000 period as measured by number of transactions announced. Based on the dollar value offered in announced acquisitions, Banking \& Finance was among the six most active industries in that same period and topped the rankings in the years 1997 and 1998.

The mechanics of the market for corporate control are determined by the legal system. Most importantly, the legal system shapes the incentive structure to which the participants in the market for corporate control respond in their actions. Moreover, the incentive structure in place has important efficiency implications. If designed optimally,

Frank A. Schmid is a senior economist at the Federal Reserve Bank of St. Louis. William Bock and Judith Hazen provided research assistance.

(C) 2002, The Federal Reserve Bank of St. Louis. society's legal system directs the self-interest of economic agents toward the optimal social outcome.

Most significant to the legal framework of the market for corporate control are the firm's articles of association and bylaws. There is also Securities and Exchange Commission (SEC) regulation, and there are the specific rules of the respective stock exchanges (such as the New York Stock Exchange, Nasdaq, and the American Stock Exchange).

Articles of association and bylaws vary across corporations. For instance, corporations may have the choice to amend their articles of association such that unsolicited bidders find it difficult to obtain control over the assets. The legal options that are available to corporations vary across state lines. For instance, a wide variety of anti-takeover amendments exist for Delaware corporations, such as supermajority rules for decisions that pertain to mergers or to the removal of board members. ${ }^{1}$ There are also cross-country differences in corporations' articles of association, which become important in crossborder merger and acquisitions transactions.

Acquisitions of publicly traded companies typically involve block trades or tender offers. In a block trade, an investor acquires a block of shares from a large shareholder. In a tender offer, an investor bids for shares that are dispersed across a multitude of mostly small shareholders. Block trades are public transactions, while tender offers are private deals. Both types of transactions might be preceded, accompanied, or followed by acquisitions of shares in the open market. Changes in control that occur through block trades are common on the European continent, where tender offers are rare. ${ }^{2}$ In the United States, on the other hand, 27 percent of all acquisitions of publicly traded companies in 2000 were brought about through tender offers (see Figure 2).

Two kinds of value matter for wealthmaximization when control over the firm changes hands. First, there is what is commonly referred to as the public value of the firm, i.e., the market value of its securities. Second, there might be a private value of the firm, through which an investor enjoys some benefit while exercising control over the firm. Private control benefits are most significant for entrepreneurial start-ups, established family-owned businesses, and organizations where personal investors also pursue non-pecuniary goals, such

\footnotetext{
1 See < http://www.uslegalforms.com/corporations/table13.htm >

2 See, for instance, Franks and Mayer (2000), who study control changes in Germany.
} 


\section{Figure 1}

\section{Acquisitions of Publicly Traded Companies}

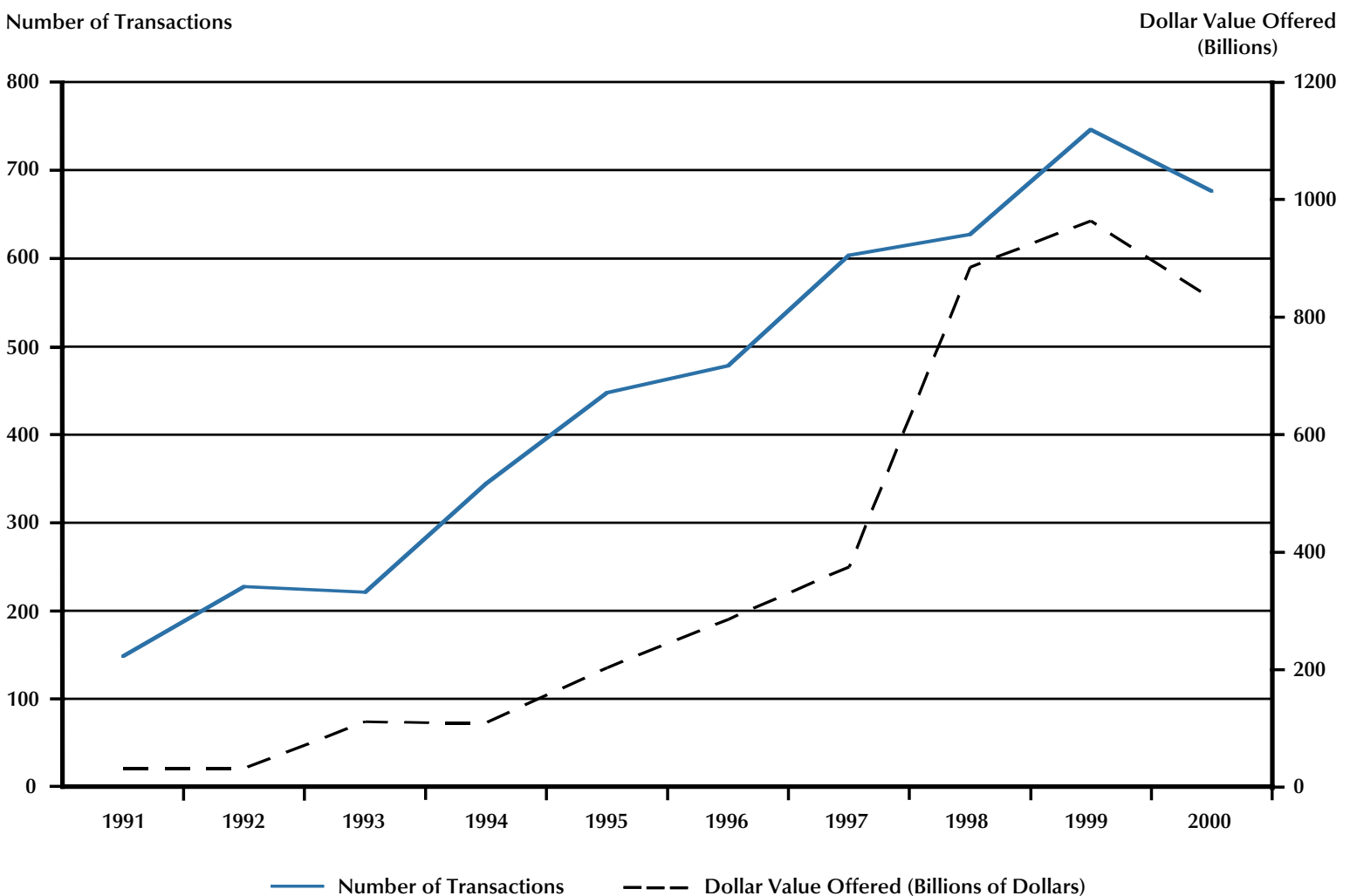

NOTE: Annual observations, 1991-2000; completed or pending transactions.

SOURCE: Mergerstat Review 2001.

as media groups and professional sports organizations. ${ }^{3}$ Maximizing social welfare necessitates that, when control changes, the sum of the public and the private values of the firm assumes its highest value. ${ }^{4}$

The following analysis assumes well-defined property rights for the various stakeholders in the firm, such as labor, bond holders, the tax authorities, suppliers, and customers. Enforceability of property rights precludes opportunistic behavior by the bidder. Absent the enforceability of such property rights, takeovers, even if they destroy value overall, might be worthwhile for the bidder if he succeeds in increasing his wealth at the expense of other stakeholders, such as bondholders and labor. ${ }^{5}$

Three institutional designs in corporate control, according to the finance literature, are most significant to wealth-maximization in takeovers: These are the one share-one vote principle, majority rules, and mandatory tender offers. We analyze the implications of these three organizational designs in a simple textbook takeover model that is drafted along the lines of Grossman and Hart (1988) and Hart (1995). The model helps define the optimal design of the legal environment in which takeovers enhance social welfare.

In the following section we present the framework that we use for analyzing the efficiency implications of institutional design as they apply to corporate control. A brief discussion of the relationship between takeovers and auctions follows. The subsequent analysis of takeovers draws on Hart (1995) but extends his analysis in several ways. We

\footnotetext{
3 See Demsetz (1983).

4 See Milgrom and Roberts (1992, pp. 35-38).

5 See Shleifer and Summers (1988).
} 


\section{Figure 2}

\section{Tender Offers Versus Other Types of Acquisitions}

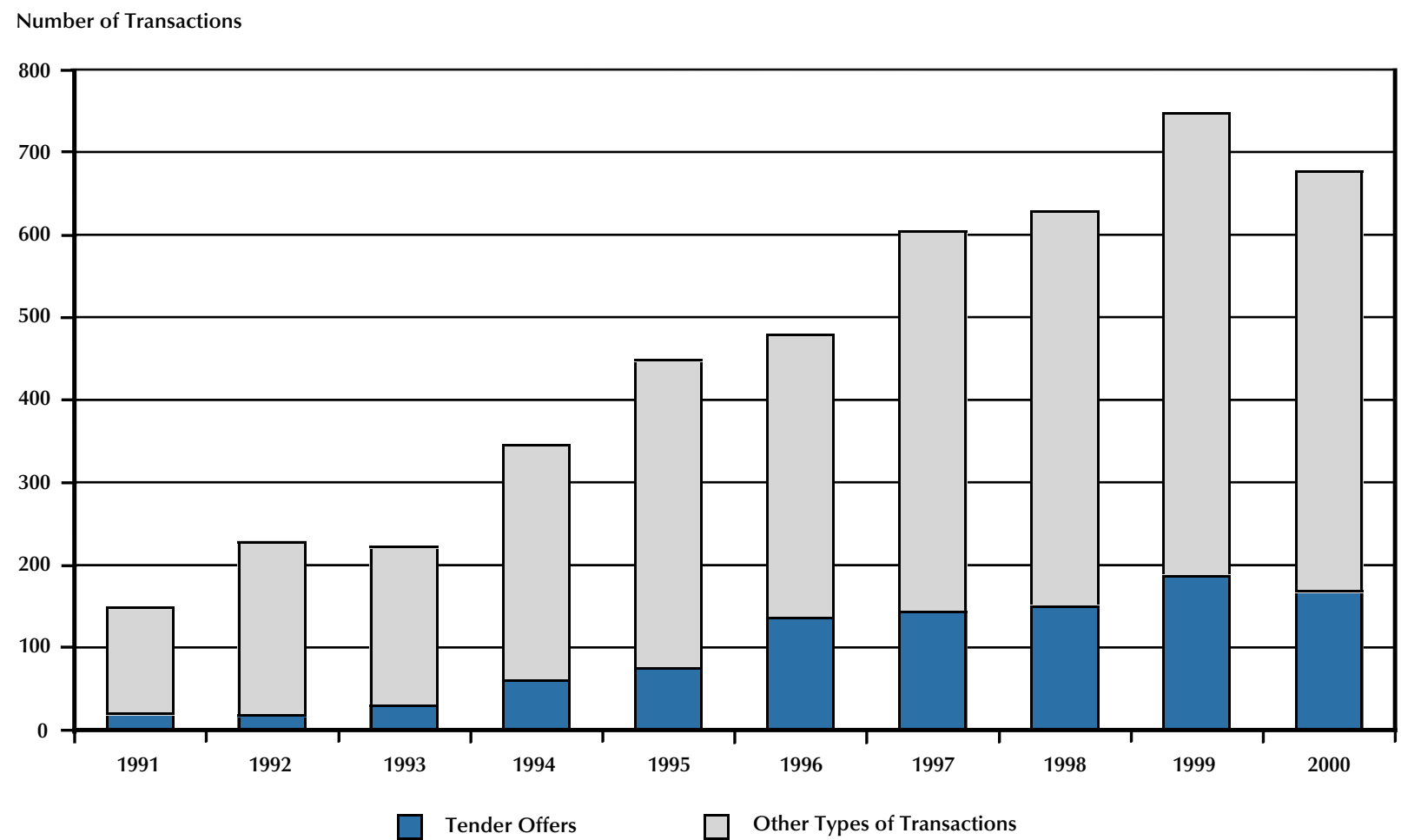

NOTE: Annual observations, 1991-2000; completed or pending transactions.

SOURCE: Mergerstat Review 2001.

address issues of free-riding in tender offers, stock ownership disclosure regulation, the one shareone vote principle, private control benefits, majority rules, and mandatory tender offers.

\section{CORPORATE CONTROL AND TAKEOVERS: AN ANALYTICAL FRAMEWORK}

Grossman and Hart (1988) and Harris and Raviv (1988) analyze the effects that deviations from the one share-one vote principle and the simple majority rule have on the value of the firm. Grossman and Hart take the perspective of the securities holders and restrict themselves to the implications for the public value of the firm. Harris and Raviv, on the other hand, take the perspective of society by looking at both the public and private values of the firm. Both papers allow for private control benefits and present the takeover mechanism as a tender offer to dispersed shareholders. No block trades among big shareholders are considered.
In Grossman and Hart (1988), the subjective probability of the small shareholder being pivotal to the outcome of a takeover attempt is zero. Harris and Raviv (1988), on the other hand, allow for this probability to be positive. This difference between the two studies explains some of the differences in results.

Grossman and Hart (1988) investigate three cases. In their first case, they look at an efficiently operated company with dual-class stock. Half the stock is voting stock, while the other half is nonvoting stock. Both classes of stocks are endowed with the same cash flow rights, and the incumbent investor does not enjoy benefits from control. Tender offers are unrestricted, which means that the bidder must take in all shares tendered to him rather than just a fraction of the stock. Grossman and Hart show that, in such a regime, a rival investor who would enjoy private control benefits but operate the firm inefficiently might succeed in obtaining control. The reason is that the investor needs to bid for the 
voting stock only. The holders of the nonvoting stock go uncompensated for the loss they suffer from the rival investor's inefficient management. In a one share-one vote regime, on the other hand, the rival investor must acquire all of the company's stock. In a tender offer under this regime, the rival investor would have to pay at least the price at which the stock is trading under the current, efficient management. Thus, the one share-one vote principle maximizes the public value of the firm.

In their second case, Grossman and Hart allow for both the incumbent and the rival investor to enjoy private control benefits. They assume that the investor who enjoys the greatest control benefits is also the investor who operates the company most efficiently. Under this assumption, the company takes on a maximum value if its stock is split into two extreme securities: one class of shares endowed with voting rights only, the other class of shares endowed with cash flow rights only. The two competing investors bid for the voting stock. The investor with the greater control benefits is more willing to pay and consequently wins out. Because this investor is also the one who runs the company efficiently, the owners of the nonvoting stock benefit as well. This scenario maximizes the public value of the firm. (Grossman and Hart point out that the assumptions made in this case are rather restrictive; the results thus cannot be read as a general recommendation for the public firm to deviate from the one shareone vote principle.)

In their third case, Grossman and Hart (1988) allow for restricted tender offers. In a restricted tender offer, the bidder can limit the shares he acquires to a pre-announced fraction. The authors show that a restricted tender offer for 50 percent of the voting stock in a one share-one vote regime is similar to an unrestricted offer in a dual-class stock regime where 50 percent of the cash flow rights are associated with nonvoting stock. Grossman and Hart also analyze the optimality of the simple majority rule, where decisionmaking requires 50 percent plus one vote. They show that the one share-one vote principle and the simple majority rule are optimal when the controlling party's private control benefits substantially exceed the rival investor's private control benefits.

In summary, Grossman and Hart (1988) show that deviations from the one share-one vote rule for public, widely held corporations are likely to be suboptimal. Deviations from the one share-one vote principle might help entrench management by insulating the firm from the market for corporate control. On the other hand, for entrepreneurial companies, issuing nonvoting stock might be optimal because it helps preserve the founding family's private control benefits.

Harris and Raviv (1988) derive results that are less ambiguous than those of Grossman and Hart (1988). As mentioned above, a major difference between the two approaches is that Harris and Raviv do not assume, as Grossman and Hart do, that the shareholder's subjective probability of being pivotal to the success of a tender offer is zero. Also, while Grossman and Hart concentrate on how to maximize the public value of the firm, Harris and Raviv look at social optimality also. Social optimality is achieved when the sum of the public and the private values of the firm takes on a maximum. Harris and Raviv show that, in a regime in which the simple majority rule and the one share-one vote principle apply, the investor that will run the firm most efficiently obtains control. While this regime ensures the socially optimal outcome, it generally does not maximize the public value of the firm. The authors show that, in a dual-class stock regime in which one class of stock has all the voting rights and the other class has all the cash flow rights, the public value of the firm takes on its maximum. This is because, with dual-class stock, the securities holders are able to extract a larger fraction of the rival investor's private control benefits. This finding is similar to an aforementioned result obtained by Grossman and Hart. In summary, Harris and Raviv show that the one share-one vote principle in combination with the simple majority rule is, in general, socially optimal because it maximizes the sum of the public and the private values of the firm. To maximize the public value of the firm, the firm should issue dual-class stock that separates voting rights from cash flow rights.

The present study follows Grossman and Hart (1988) in that we assume that the subjective probability of the small shareholder being pivotal to the takeover success is zero. Like Harris and Raviv (1988), the focus is on maximizing social welfare rather than just the public value of the firm. In contrast to any of these studies, the analysis is not restricted to tender offers, but also allows for block trades. Also, hold-up situations that supermajorities might create are discussed, as is the potentially beneficial role of mandatory tender offers. 


\section{TAKEOVERS AND AUCTIONS}

Takeovers are typically brought about through successful tender offers or block trades. In both types of transactions, there is at least one bidder extending an offer to the firm's current equity holders. When a rival bidder contests the offer, the takeover resembles an auction. In takeovers, the auctioned object is control over the firm, which is tied to the firm's voting stock.

There are common value and private value auctions. In common value auctions, there are no benefits arising from equity ownership that are not common to all bidders. The common value in takeovers is the present value of the firm's cash flows. In private value auctions, on the other hand, the value of the firm depends on the bidder. Private value matters in takeovers if bidders derive private benefits from exercising control over the firm. In such cases, the firm might then be valued above the present value of its cash flows.

In auctions, the current owners have reservation prices. A reservation price is the price below which the current owner is not willing to trade. For reservations prices, too, private benefits might matter. For instance, if the takeover target is an entrepreneurial firm, it is likely that due to the entrepreneur's private control benefits the reservation price of the seller exceeds the present value of the auctioned firm's cash flows.

Takeover bidding resembles English auctions, which have an ascending bid structure, and the auctioned firm goes to the investor who submits the highest bid. Although this outcome is efficient, the firm might sell for a price that is less than the winning bidder is willing to pay. Such an outcome is possible because all it takes to win the bid is an offer that supersedes, even by the smallest possible increment, the bidder with the next-to-highest willingness to pay. ${ }^{6}$

\section{The Winner's Curse}

In a takeover, a bidder might overpay because he overestimates the target firm's present value of cash flows. ${ }^{7}$ Even if the bidder has unbiased expectations, a random error in these expectations may cause his willingness to pay to exceed the firm's intrinsic value. This phenomenon is called the winner's curse. ${ }^{8}$ Below we illustrate the concept of the winner's curse in two examples. The first example shows that a winning bidder need not overpay even if he overestimates the intrinsic value of the auc- tioned object. The second example is a case in which a bidder who overestimates does indeed overpay. To keep matters simple, we illustrate the winner's curse for a common value auction.

In this first example, assume that there are two bidders, A and D. Both bidders have unbiased expectations about the present value of the firm's future cash flows, which equals $\$ 100$. Because of a random element in expectations, D estimates the intrinsic value of the target at $\$ 102$, while A estimates it at $\$ 98 .{ }^{9}$ While both bidders' expectations are off the mark, as a group the bidders' expectations are correct (unbiased). In a bidding contest, D will end up with the firm at a price marginally above $\$ 98$, without overpaying.

In the second example, assume there are two additional bidders, $B$ and $C$, in addition to bidders $A$ and $D$ from the first example. The expectations of bidders B and C about future cash flows are $\$ 99$ and $\$ 101$, respectively. Again, as a group the expectations of the four bidders are unbiased as they average the intrinsic value of the auctioned object. As in the first example, D wins out. This time, D pays marginally more than $\$ 101$. Although D pays less than he is willing to pay, he nevertheless overpays because the intrinsic value of the auctioned firm is only $\$ 100$.

In summary, the winner's curse concept rests on estimation errors, although these estimation errors need not be systematic. The winning bidder might, but need not, overpay. As the number of bidders rises, however, the probability that the winning bidder overpays increases, all else equal.

Empirical studies show that in takeover contests all the gains (if any) tend to go to the shareholders of the target firm. On average, the shareholders of the acquiring firm break even. There is no evidence that in takeovers bidders overpay systematically; in

6 In Dutch auctions, the bid structure is descending. The auctioneer calls prices in descending order, and the first bidder to shout "mine" wins out. See Milgrom (1989).

7 If the bidder is a company that merges the target into its existing operations, the value the bidder assigns to the target is not the present value of the target firm's cash flows on a stand-alone basis. Rather, it is the difference between the present value of the cash flows of the combined firm and the sum of the present values of the cash flows of the two firms when operating on a stand-alone basis.

8 For an overview on the winner's curse, see Milgrom (1989) and Thaler (1988).

9 The two bidders' expectations may be viewed as independent draws from the same probability distribution, which is symmetric around the expected value. 
the following sections, we make use of this empirical finding. ${ }^{10}$ We exclude overpaying by assuming that the intrinsic value of the firm is public knowledge.

\section{TENDER OFFERS AND FREE-RIDING}

Tender offers are public bids for stock in which investors can tender their shares in the target firm to a bidder at a certain price within a certain time window. As mentioned above, tender offers are called restricted if this offer applies to a certain fraction of shares only. Otherwise, the offers are called unrestricted. In addition, tender offers may be conditional or unconditional. If the offer is conditional, the bidder is not obliged to acquire the tendered shares if their fraction in the total outstanding stock falls short of a pre-announced minimum.

In tender offers, the shares are typically dispersed among small shareholders. The dispersion of the shares gives rise to a free-riding problem, which might thwart value-enhancing takeovers. In the following, we analyze the free-riding problem in a common value bidding contest. Because the free-riding problem is independent of the number of bidders, one can assume without loss of generality that there is no rival bidder contesting the takeover attempt.

Assume that there is a target company with 2 million shareholders, each holding one share. Before news of the bid reaches the market, the target trades at $\$ 1$ a share. The bidder is a buyout fund that plans on taking control of the firm and improving the efficiency of the operations. The bidder expects this transaction to add $\$ 1$ million (or $\$ 0.5$ per share) to the target's present value of cash flows. We assume that the value added is public knowledge. This is a reasonable assumption for large, traded firms, which are closely followed by financial analysts.

For each shareholder of the target firm, the objective probability that his decision is pivotal to the success of the takeover, or to the bidder's decision to better the offer while it is outstanding, is only marginally greater than zero. ${ }^{11}$ We follow Grossman and Hart (1988) in assuming that each shareholder's subjective probability of being pivotal is zero. This assumption implies that small shareholders are unable to enjoy control benefits.

We assume that the tender offer is conditional (restricted or unrestricted), which means that the bidder acquires the tendered shares only if he succeeds in seizing control. In the absence of super- majority rules, we set the control threshold to 50 percent plus one share.

In the first example, assume that the bidder owns no stock in the target when launching the tender offer. The target firm's shareholders have an incentive not to tender if the bid falls short of the stock's post-takeover value. This response occurs because no shareholder assumes that his decision is pivotal to the outcome of the takeover attempt and each shareholder therefore pursues his best interest. By doing so, however, the shareholders thwart the efficient social outcome. If, for instance, the bidder offers $\$ 1.4$ a share, the target shareholder will end up with $\$ 1.4$ if he tenders and the takeover succeeds. If he tenders and the takeover fails, he winds up with $\$ 1$. On the contrary, if he does not tender, the payoffs in these two situations are $\$ 1.5$ and $\$ 1$, respectively. Thus, for the target shareholder, it is optimal not to tender in response to a bid that falls short of the post-takeover share price. On the other hand, for the bidder, a price of $\$ 1.5$ or higher is unprofitable. Consequently, the takeover-in spite of being value-enhancing-does not materialize.

In the second example, assume that the bidder acquired a toehold in the target firm in the open market at $\$ 1$ a share before announcing the tender offer. Again, the target shareholder does not tender unless the bid matches the post-takeover share price of $\$ 1.5$. Because of the toehold, the bidder is able to reap part of the value added even when paying $\$ 1.5$ a share. If, for instance, the toehold amounts to 5 percent, the bidder retains $\$ 50,000$ of the value added, while the other $\$ 950,000$ go to the target shareholders. ${ }^{12}$ The takeover materializes, and the efficient outcome obtains. ${ }^{13}$

In the third example, assume that the rival investor is a wealthy individual who enjoys benefits from having control. When announcing the bid, the investor holds no stock in the target firm. The bidder values the private control benefits at $\$ 150,000$.

\footnotetext{
${ }^{10}$ For a survey on empirical studies on post-takeover performance, see Weston, Chung, and Siu (1998).

11 Takeover regulation typically requires that when an outstanding bid is bettered, the new price uniformly applies to all tendered shares, including those that have already been tendered.

12 Many jurisdictions around the world restrict the size of toeholds that investors can accumulate without having to disclose it to the public, the target firm, or the competent stock market supervisory authority. For instance, the threshold for disclosure might equal 5 percent of the company's total equity or the equity within a certain class of stock.

${ }^{13}$ For an extensive analysis on the role of toeholds on the success of takeovers, see Shleifer and Vishny (1986).
} 
Thus, if the takeover succeeds, another $\$ 150,000$ in value is added because of private control benefits, beyond the $\$ 1$ million the investor would add through improving the target firm's operations. The total value added through the takeover would amount to $\$ 1.15$ million. Similar to toeholds, private control benefits help overcome the free-riding problem in tender offers. The target shareholders' payoff matrix is identical to the first two examples. The bidder is willing to pay a price equal to the posttakeover (public) value of the target ( $\$ 1.5$ a share) because the takeover allows the entrepreneur to realize private control benefits equivalent to $\$ 150,000$.

The above examples assumed the tender offers to be conditional. It turns out that the incentives that prevail in an otherwise identical unconditional tender offer are more conducive to a successful takeover. In the first example discussed above, if the tender offer were unconditional, the target shareholder would receive $\$ 1.4$ for certain if he tendered, with no change in payoff if he did not tender. This means that the shareholder is more likely to tender if the tender offer is unconditional. For instance, if the small shareholder attaches equal probabilities to the takeover failing or coming to pass, the expected value of the share if not tendered amounts to $\$ 1.25$, which is short of the risk-free $\$ 1.4$ paid on the tendered share.

Another instrument for solving the free-riding problem is the two-tier offer. The bidder makes a favorable "front end" offer for the fraction of shares he needs to obtain control and an unfavorable "back end" offer for the remainder. For instance, a bidding corporation might offer cash for the first 50 percent plus one share and newly issued shares for the remainder. ${ }^{14}$ After the bidder obtains control through the cash offer, the bidder might find ways of depressing the firm's public value before forging a "back-end" merger under conditions favorable to him. One way to depress the value is to dilute the firm's earnings. Dilution of earnings is possible, for instance, through asset transfers or through transfer pricing of inter-firm trade in intermediate products. Transfer pricing and asset transfers below fair market value violate the arm's-length principle and might be illegal, depending on the jurisdiction. ${ }^{15}$ Also, as two-tier offers discriminate between frontend purchase and back-end conversion, the investor might violate duties of equal shareholder treatment. The tender offer is coercive, as the shareholders feel compelled to be in the first tier.

\section{THE ONE SHARE-ONE VOTE PRINCIPLE}

Harris and Raviv (1988) have shown that the one share-one vote principle is generally optimal for society and suboptimal for the securities holders. Also, Grossman and Hart (1988) have shown that deviations from the one share-one vote rule might be optimal from the securities holders' point of view. In the following, the implications of violations of the one share-one vote principle for the value of the firm is analyzed in two numerical examples.

Firms might deviate from the one share-one vote rule by issuing preferred stock, which may be either stock endowed with multiple votes or nonvoting stock with preferred cash flow rights. In some jurisdictions, issuing stock with multiple votes is prohibited. Also, legislation might limit nonvoting stock to a certain fraction of the firm's total equity.

We analyze a firm with dual-class stock. Class A stock is common (voting) stock, and class B stock is preferred (nonvoting) stock. Each class of stock is endowed with the same cash flow rights. As above, we allow for two types of investors: block holders and small shareholders. We maintain the assumption that shareholders are investors who each hold one share and attach a subjective probability of zero to being pivotal to the success of a takeover attempt. Class B stock is held entirely by small shareholders-because they do not value control anyway - whereas class A stock might be held by small shareholders or by block holders. We also assume that the marginal investor in class A stock is a small shareholder, which means that both classes of stock trade at the same price. ${ }^{16}$ In each class of stock, there are 1 million shares outstanding.

In this first example, we assume that initially all A shares are held by small shareholders. The firm operates efficiently, and class A and class B stocks trade at $\$ 1$ a share. Assume that there is an investor who-if he were in control-would enjoy private control benefits but would not run the firm

\footnotetext{
${ }^{14}$ Prorating applies if more than 50 percent plus one share are tendered in the first tier. We assume that there is no supermajority rule in place.

15 The arm's length principle stipulates that trade among affiliated companies has to be conducted at prices that would prevail in corresponding market transactions with unaffiliated companies.

${ }^{16}$ It is the marginal investor that prices financial assets. Empirically, nonvoting stock may trade higher or lower than voting stock. While the lack of control rights creates a discount on nonvoting stock, preferential cash flow rights generate a premium. Also, for entrepreneurial firms, the float of nonvoting stock frequently exceeds the float of voting stock, which generates a liquidity discount on the voting stock.
} 
efficiently. For instance, with this investor in control, the private value of the firm (which is the monetary equivalent of the control benefits) might equal $\$ 150,000$ and the public value of the firm might amount to $\$ 0.9$ a share. The decrease in public value might be due to the fact that the investor employs firm resources to generate private benefits, for instance in the form of luxurious offices and lavish business dinners. If the investor succeeded in taking over the firm, social welfare would decrease by $\$ 50,000$. This is because the sum of the post-takeover public and private values $(\$ 1,950,000)$ falls short of the company's pre-takeover value ( $\$ 2$ million).

The investor can obtain control over the firm by acquiring a minimum amount of class A shares, which - in the absence of supermajority rules -is 50 percent plus one share. If the investor bids $\$ 1.01$ a share for the class A shares in a (unrestricted and unconditional) tender offer, the takeover attempt will be successful. This holds in spite of its valuedepressing effect on society. At $\$ 1.01$ a share, the small shareholder tenders. If the small shareholder does not tender, his position is worth $\$ 0.9$ if the takeover succeeds and remains at $\$ 1$ if it does not succeed. On the other hand, if the small shareholder tenders, he receives $\$ 1.01$ for certain. Consequently, all shareholders tender their interests and the takeover succeeds. The investor loses $\$ 110,000$ on his investment in A shares, but gains $\$ 150,000$ in private control benefits. The loss to society $(\$ 50,000)$ is the difference between the decrease in public value $(\$ 100,000)$ and the increase in private control benefits $(\$ 50,000)$.

By comparison, the one share-one vote principle generates the efficient outcome by giving the investor no incentive to bid. Under the one shareone vote rule, the investor has to extend a tender offer to all shareholders by bidding $\$ 1.01$ for each of the 2 million shares. The investor would lose $\$ 220,000$ on the equity interest but gain only the equivalent of $\$ 150,000$ in control benefits. A takeover succeeds if (and only if) the total value added is positive, which means that the gain in private benefits must exceed the loss in public value. ${ }^{17}$ Note that even a toehold would not help the investor succeed in the takeover attempt.

In the second example, we assume that the firm in question is family-owned. The family holds all of the class A shares, but none of the nonvoting stock. The public value of the firm equals $\$ 1.8$ million with the B shares trading at $\$ 0.9$ a share. ${ }^{18}$ The family enjoys private control benefits equivalent to $\$ 150,000$.
In many countries, dual-class stock is a common phenomenon with family-owned companies. Frequently, as entrepreneurial firms grow, the wealthconstrained founding family is unable to maintain its fraction of equity in the firm following public offerings. By issuing nonvoting stock, the family might be able to retain control even after floating equity in the stock market.

Assume that the founding family is in its second generation and that the entrepreneurial skills left the company when the founder left. An institutional investor - a buyout fund, for instance - might be able to run the company more efficiently, without enjoying control benefits. Assume that, if the buyout fund were in control, the public value of the company would amount to $\$ 2$ million, with B shares trading at $\$ 1$ a share. Although society would be better off, scoring a net gain of $\$ 50,000$, in a dualclass stock regime the optimal outcome does not obtain. This occurs because, to the family, the class A equity interest is worth $\$ 1,050,000$ (private value of $\$ 150,000$ plus public value of $\$ 900,000$ ), which exceeds the post-takeover public value of the class A stock by $\$ 50,000$.

The takeover can succeed in spite of the presence of dual-class stock if the buyout fund acquires an interest in class B stock before bidding for the family's stake. If the investor-before revealing the takeover plan-accumulated a position in B shares in excess of 50 percent in the open market at a price of $\$ 0.9$, he would be able to buy out the family. This outcome can occur because the capital gain on the class B equity position would exceed the difference between the family's and the buyout fund's valuations of the class A equity. The buyout fund could pursue this strategy only if there were no stock ownership disclosure rules that would force the investor to reveal the buildup of the class $B$ interest in the early stages of the buyout. Once the buyout fund's intentions leak to the market, B shareholders have an incentive to free-ride.

In the one share-one vote regime the situation is similar. With the family holding 50 percent (plus one share) of the voting stock and the rest being dispersed, the only way a rival investor can seize control is to buy out the family. The same incentives

\footnotetext{
${ }^{17}$ If the private benefits the investor enjoys are sufficiently low, or the inefficiency the investor causes is sufficiently high, the optimal outcome also prevails in the dual-class stock regime.

18 Note that A shares do not trade. With B shares trading at \$0.9 a share the shadow price of the family's stake equals $\$ 900,000$.
} 
that were relevant in the dual-class stock regime apply in the one share-one vote regime. If the buyout fund is unable to accumulate (secretly) a position in excess of 25 percent in the open market at $\$ 0.9$ a share, the investor has no incentive to bid for the family's equity interest.

The equivalence in outcomes in the two regimes is due to the specific assumptions made in the example. First, the fraction of voting stock was limited to 50 percent of the company's total equity; second, no supermajority rule was in place. Under such conditions, family owners have no incentive to issue nonvoting stock in lieu of voting stock. However, if the law requires supermajorities for certain decisions, the equivalence breaks down and dual-class stock becomes an important tool for protecting the family owner's private control benefits. This is discussed in the next section.

\section{PRIVATE BENEFITS, SUPERMAJORITY RULES, AND DUAL-CLASS STOCK}

In some jurisdictions around the world, corporate law mandates that certain decisions at annual meetings require supermajorities of two-thirds or 75 percent of the votes. Among the issues that are typically subject to supermajority rules are changes to the company's equity (e.g., securities offerings or stock repurchases) and major changes to assets (e.g., mergers and major acquisitions). The existence of supermajority rules implies the existence of blocking minority rules. For instance, with a 75 percent supermajority rule in place, a block holder can paralyze a corporation when holding 25 percent plus one vote. A blocking minority interest creates bargaining power vis-à-vis a family owner whose holding might have dropped below the 75 percent threshold due to a binding wealth constraint. Generally, supermajority rules imply that family owners must retain greater fractions of shares to stay in control. In the following we show that the one share-one vote regime is not necessarily optimal when private control benefits exist and corporate law mandates supermajorities for important decisions.

As an example, assume an entrepreneurial firm where the owner family's fraction of voting stock amounts to 60 percent. The remaining 40 percent have been floated in the stock market as the company expanded through public offerings and the family was unable to acquire the additional stock due to its limited wealth. Assume that dual-class stock is prohibited and that the law mandates a 75 percent supermajority for major corporate decisions. The company is run efficiently. The stock trades at $\$ 1$ a share with a 1.2 million share float, which is dispersed. Effectively, the entrepreneur has command over the necessary supermajority. Dispersed shareholders exercise no control, because they view their probabilities of being pivotal as zero. Also, because the company is run efficiently, the shareholders have no incentive to reject or disapprove of the entrepreneur's operating decisions. The entrepreneur enjoys private control benefits, which he values at $\$ 150,000$.

Assume that there is a rival investor who attaches a monetary equivalent of $\$ 75,000$ to the control rights that come with a blocking minority interest in the company in question. The control benefits might emanate from personal pleasure of influencing the business decisions of this particular company or from reduced competition if the investor is a rival. ${ }^{19}$ Assume that the rival investor's business goals are at odds with those of the entrepreneur, which paralyzes decisionmaking. The gridlock reduces the present value of the firm's cash flows from $\$ 2$ million to $\$ 1.8$ million.

If the rival investor accumulates a block of 25 percent plus one share in the open market at $\$ 1 \mathrm{a}$ share and pursues the business strategy outlined above, he will lose a little more than $\$ 50,000$ on the acquired shares but gain $\$ 75,000$ in private control benefits. At the same time, the value of the remaining equity ( 75 percent minus one share) drops by a little less than $\$ 150,000$. Also, the family loses its control benefits of $\$ 150,000$ in part or in total. Overall, the net loss to society amounts to at least $\$ 125,000$ (and at most $\$ 275,000$ ). Despite the one share-one vote rule in place, the inefficient outcome prevails. ${ }^{20}$

With dual-class stock, the value-reducing control change can be prevented. Assume that the entrepreneur is allowed to issue nonvoting stock at a maximum of 50 percent of the corporation's

\footnotetext{
${ }^{19}$ For instance, for certain decisions, the German Stock Corporation Act requires supermajorities at annual shareholder meetings. In Germany, it has repeatedly been observed (in particular in the media industry) that investors take blocking minority interests in competitors, which all but paralyzes these companies before the original owners eventually surrender their stakes.

20 If the small shareholders anticipate the decrease in the public value of the firm and assume that it will be sustained, they sell to the outside investor at $\$ 0.9$ a share. This does not affect the change in wealth to society overall, but affects solely the distribution of wealth between the original (small) shareholders and the outside block holder.
} 
total equity. With a 60 percent ownership of total equity, the entrepreneur is able to retain all the voting stock (and also holds 20 percent of the nonvoting stock). The rival investor has no means of seizing control over the firm without fully compensating the family owner. This scenario implies that, if the rival is not able to generate at least as much value as the incumbent, he is unable to gain control. Thus we conclude that in the presence of supermajority rules (i.e., blocking minority rules), the entrepreneurial firm should be allowed to deviate from the one share-one vote rule by issuing nonvoting stock.

\section{BLOCK TRADES}

In some of the examples above we have alluded to block trades as a means of transferring control over the firm. An example of a block trade is when a family sells out to a single investor rather than floating the block of shares in the stock market. Block trades are private deals rather than openmarket transactions. It has been observed that in block trades the price per share exceeds the going share price in the open market. ${ }^{21}$ The concept of the Nash bargaining solution offers a possible explanation for the existence of such block premiums. In a Nash bargaining solution the two parties share the surplus from cooperation evenly. ${ }^{22}$

To illustrate the block premium as it evolves from a Nash bargaining solution, we look at the example from the preceding section where, in a one share-one vote regime, a rival investor paralyzes an entrepreneurial corporation. We assume that, if the rival took full control by buying out the family owner, the present value of the company's cash flows would be back to what it was prior to the rival investor taking a blocking minority interest. This situation implies that the rival has an incentive to pursue a cooperative strategy by bidding for the family's equity stake; in this way he could increase the value of his original position of 25 percent plus one share by a little more than $\$ 50,000$. Conversely, it may be advantageous for the family to accept the bid. If, for instance, the family has lost all its private control benefits, selling out to the intruder becomes advantageous as it allows the family to reap capital gains on its 60 percent equity stake.

Two cooperative outcomes are conceivable. Either the family sells out to the rival investor, or the rival sells out to the family. If the family buys out the rival, he (or any other investor with similar preferences) would repeat this game ad infinitum.
This is because, by selling out, the investor would generate gains from cooperation, which - in a Nash bargaining solution - are shared evenly by the two parties. This means that the rival investor does not only gain when acquiring the blocking minority interest, he also gains when selling it. Thus, the only viable strategy is that the family sells out to the rival (which assumes that the rival investor's wealth constraint is not binding).

In the noncooperative situation (in which the rival investor paralyzes the company), the family's wealth equals $\$ 1,080,000$ (the equity interest of the family, which has lost all its control benefits). The wealth of the rival investor amounts to a little more than $\$ 525,000$ (the rival investor's financial position plus his control benefits). Added up between the two parties, total wealth is little more than $\$ 1,605,000$. If the family sells out, total wealth increases to a little more than $\$ 1,775,000$ (assuming that the intruder's control benefits remain unchanged). The gain from cooperation equals a little more than $\$ 170,000$, which is shared evenly between the two parties. Consequently, the block of shares changes hands at a little more than $\$ 1,165,000$, which implies a price per share of about $\$ 0.97$. This is $\$ 0.07$ above the company's share price based on the present value of cash flows in the noncooperative state.

Compared with the situation before the intruder shows up at the company's gates, the family loses (a little less than) $\$ 185,000$, while the intruder gains (a little less than) $\$ 110,000$. Society as a whole loses $\$ 75,000$, which is the difference between the family's control benefits $(\$ 150,000)$ and the intruder's private benefits $(\$ 75,000)$. The intruder winds up with 85 percent of the voting stock.

\section{MANDATORY TENDER OFFERS}

With a mandatory offer rule in place, an investor has to make a tender offer for the remaining shares once he has obtained control. The U.K. "City Code" offers the most prominent example of takeover regulation with a mandatory tender offer in place. Control in the U.K. City Code is defined as 30 percent of the voting stock. 23 Once an investor

\footnotetext{
${ }^{21}$ See, for instance, Franks and Mayer (2000).

${ }^{22}$ For a textbook example of the Nash bargaining solution, see Hart (1995).

${ }^{23}$ For "City Code on Takeovers and Mergers and the Rules Governing Substantial Acquisition of Shares," see < http://www.thetakeoverpanel org.uk >
} 
reaches or crosses this threshold from below, he has to make an (unconditional) offer for all remaining shares. In the following we show that mandatory tender offers protect small shareholders against block trades in which the trading parties gain at the expense of the small shareholders.

In this first example, there is no mandatory tender offer rule in place. We look at a company with 2 million shares outstanding. All shares are voting stock. An institutional investor holds the majority of shares (50 percent plus one share), with the remaining shares being dispersed. The incumbent investor operates the corporation efficiently but-because it is an institution rather than an individual-generates no private control benefits. The company trades at $\$ 1$ a share. We assume that there is no supermajority rule in place.

Suppose there is a private investor who, if he were in control, would enjoy private control benefits but would not run the firm efficiently. For instance, if the investor were to gain control, the private value of the firm would equal $\$ 150,000$ and the public value of the firm would amount to $\$ 0.9$ a share. The drop in the company's public value might be due to the investor's funding of perquisites through the company.

If control changed from the institutional to the private investor, society would lose $\$ 50,000$. We show that, without a mandatory tender offer rule in place, the takeover indeed happens. In contrast, with mandatory tender offer regulation, the efficient outcome prevails.

As outlined above, in a Nash bargaining solution the two parties share the surplus from cooperation evenly. The surplus generated for the two parties when control changes from the institutional investor to the private investor equals a little less than $\$ 50,000$. Splitting the surplus evenly would imply a price for the 50 percent-plus-one-vote block of a little more than $\$ 1,025,000$. By selling out, the institutional investor gains a little less than $\$ 25,000$, and so does the personal investor. Society overall loses $\$ 50,000$. The small shareholders suffer a loss close to $\$ 100,000$.

With mandatory takeover regulation in place, an investor does not succeed in taking over an efficiently operated firm if he is unable to add value to society. This is because the investor must acquire all shares. He always pays at least fair market value, be it in block trades or open market operations prior to taking control or in the mandatory tender offer.

While the arguments put forward in favor of mandatory tender offers are strong, it is noteworthy that this rule does not find unanimous support among traded corporations. For instance, Germany introduced a takeover code in 1995 as a voluntary guideline. As of April 11, 2000, only 540 of 933 listed German firms had signed the Takeover Code. Among the companies that have not signed on are BMW AG and Volkswagen AG. ${ }^{24}$ A possible reason why companies find the code objectionable is that a mandatory tender offer rule does not allow them to hold minority positions in companies to protect relationspecific investments. Automobile companies frequently take positions in subcontractors to insulate themselves against opportunistic behavior. This position is most important where suppliers also provide part or all of the research and development that pertains to the delivered intermediate products. ${ }^{25}$

\section{CONCLUSION}

In a series of numerical examples we analyzed the impact of the one share-one vote principle, the simple majority rule, and mandatory tender offer regulation from the perspective of a socially optimal market for corporate control. Maximizing social welfare means maximizing the sum of the private and public values of the firm, rather than maximizing public value only. While our analysis is too simple to draw policy conclusions, we agree with Harris and Raviv (1988) that the simultaneous presence of the one share-one vote principle and the simple majority rule is generally optimal. At the same time, the analysis lends strong support to prohibiting restricted tender offers and to legalizing mandatory tender offers.

The simple majority rule ensures that the incumbent investor and the rival investor are on equal footing. The one share-one vote principle in combination with a mandatory tender offer regulation forces the rival investor to acquire all the cash flow rights if he wants to obtain control. This prevents value-decreasing takeovers because the rival investor succeeds only if he is able to raise the sum of the private and the public values of the firm beyond the level that comes with the incumbent investor.

\footnotetext{
24 For details, see the German Takeover Commission's Web site at $<$ http://www.kodex.de $>$. The site also posts the list of signatories. As a result of the low acceptance of the Takeover Code, the commission recommended to the legislature to write the code (in a revised form) into law.

${ }^{25}$ For a classic study on subcontracting relations in the automobile sector, see Asanuma (1989), who analyzes Toyota Motor Company.
} 
Mandatory supermajority rules appear to be particularly harmful to society. On one hand, full control requires more than 50 percent (plus one share) of the voting stock, which puts the rival investor at a disadvantage in relation to the incumbent. On the other hand, a minority interest is sufficient to block important decisions. An investor who holds a minority interest can paralyze the firm and expropriate the incumbent investor of his private control benefits. The situation can be avoided with a mandatory tender offer where the offer threshold is set to the blocking minority threshold. Generally, mandatory supermajority rules should come with mandatory tender offers.

\section{REFERENCES}

Asanuma, Banri. "Manufacturer-Supplier Relationships in Japan and the Concept of Relation-Specific Skill." Journal of the Japanese and International Economies, March 1989, 3(1), pp. 1-30.

Demsetz, Harold. "The Structure of Ownership and the Theory of the Firm." Journal of Law and Economics, June 1983, 26(2), pp. 375-90.

Franks, Julian and Mayer, Colin. "Ownership and Control of German Corporations." Working Paper, University of Oxford, 2000.

Grossman, Sanford J. and Hart, Oliver D. "One Share-One Vote and the Market for Corporate Control." Journal of Financial Economics, January/March 1988, 20(1/2), pp. 175-202.
Harris, Milton and Raviv, Artur. "Corporate Governance: Voting Rights and Majority Rules.” Journal of Financial Economics, January/March 1988, 20(1/2), pp. 203-35.

Hart, Oliver. Firms, Contracts, and Financial Structure. Oxford: Clarendon Press, 1995.

Mergerstat. Mergerstat Review 2001. Los Angeles: Applied Financial Information LP, 2001.

Milgrom, Paul. "Auctions and Bidding: A Primer." Journal of Economic Perspectives, Summer 1989, 3(3), pp. 3-22.

and Roberts, John. Economics, Organization and Management. Englewood Cliffs, NJ: Prentice Hall, 1992.

Myers, Stewart C. "Outside Equity.” Journal of Finance, June 2000, 55(3), pp. 1005-37.

Shleifer, Andrei and Summers, Lawrence H. "Breach of Trust in Hostile Takeovers," in Alan J. Auerbach, ed., Corporate Takeovers: Causes and Consequences. Chicago: University of Chicago Press, 1988, pp. 33-56.

and Vishny, Robert W. "Large Shareholders and Corporate Control." Journal of Political Economy, June 1986, 94(3, Part 1), pp. 461-88.

Thaler, Richard H. "Anomalies: The Winner's Curse." Journal of Economic Perspectives, Winter 1988, 2(1), pp. 191-202.

Weston, J. Fred; Chung, Kwang S. and Siu, Juan A. Takeovers, Restructuring, and Corporate Governance. Second edition. Upper Saddle River, NJ: Prentice Hall, 1998. 